\title{
Rapid Decrease of Bronchial Cuff Pressure Indicates Slippage of the Bronchial Cuff
}

\author{
Yihong Jiang ${ }^{* 1,3}$, Yoshito Shiraishi ${ }^{* 2}$, Yoshitaka Aoki ${ }^{* 3}$, Shigehito Sato*3
}

\begin{abstract}
[Abstract] Purpose : This study aimed to investigate whether or not bronchial cuff pressure decreases when the cuff slips from the bronchial lumen while shifting from the supine to the lateral position.

Methods : After the induction of general anesthesia, 18 patients underwent tracheal intubation using a double-lumen tube(DLT). Following confirmation of the position of the DLT by fiberoptic bronchoscopy, the minimum volume of air was injected into both tracheal and bronchial cuffs to avoid gas leakage. The pressure of both cuffs was recorded before and after shifting from the supine to the lateral position. Using a fiberoptic bronchoscope, we confirmed the position of the bronchial cuff, and investigated the relationship between the change of cuff pressure and slippage of the cuff.

Results : The bronchial cuff pressure decreased from $21.2 \pm 2.4 \mathrm{cmH}_{2} \mathrm{O}$ in the supine position to $15.2 \pm 7.8 \mathrm{cmH}_{2} \mathrm{O}$ in the lateral position (mean $\pm \mathrm{SD}, P=0.003$ ). We confirmed a rapid decrease of more than $10 \mathrm{cmH}_{2} \mathrm{O}$ in the cuff pressures in 6 cases, and all of these bronchial cuffs were found to be partly slipping out of the lumen.

Conclusion: The bronchial cuff pressure of the DLT decreased when changing from the supine to the lateral position. The rapid decrease of bronchial cuff pressure $\left(>10 \mathrm{cmH}_{2} \mathrm{O}\right)$ seems to be due to slippage of the bronchial cuff from the bronchial lumen. Continuous monitoring of bronchial cuff pressure is necessary to detect slippage of the bronchial cuff.

Key Words : Bronchial cuff pressure, Double-lumen tube, Slippage of the bronchial cuff
\end{abstract}

(JJSCA Vol.27 No.3, 253 258, 2007)

\section{Introduction}

Double-lumen tube (DLT) has been used to achieve isolation of the lung during thoracic surgery ${ }^{1,2)}$. However, when the DLT is used for pulmonary or esophageal surgery, the insufficient isolation of the DLT results in anesthetic gas leakage and pulmonary aspiration.

Following placement of the DLT, we generally confirm the position of the distal end of the tube
Received Jun. 15, 2006 ; Accepted Feb. 23, 2007

${ }^{*}$ Department of Anesthesiology, Affiliated Hospital of Guilin

Medical College, Guilin, China

*2Department of Surgical Operating Center, Hamamatsu

University Hospital, Hamamatsu, Japan

*3Department of Anesthesiology and Intensive Care, Hamamatsu

University School of Medicine, Hamamatsu, Japan
Corresponding author : Yoshito Shiraishi

Department of Surgical Operating Center.

Hamamatsu University Hospital,

1-20-1 Handayama, Hamamatsu, Shizuoka

431-3192, Japan 
and the bronchial cuff using fiberoptic bronchoscopy. After changing from the supine to the lateral position, we again confirm the bronchial cuff position using fiberoptic bronchoscopy.

Many investigators have reported the relationship between a decrease in bronchial cuff pressure and partial slippage of the cuff following a shift from the supine to the lateral position ${ }^{3)-5)}$. Moreover, Karasawa et al. demonstrated the decrease in bronchial cuff pressure after cessation anesthetized with nitrous oxide ${ }^{6}$. However, the critical decrease in pressure that indicates slippage of the bronchial cuff has not been investigated. In the present study, we attempted to determine this critical decrease in pressure before and after a change in the position of the patient.

\section{Materials and methods}

Eighteen patients (aged 32-76 years, ASA physical status class I or II) undergoing pulmonary surgery requiring lung isolation were intubated using a left double-lumen tube (Broncho-Cath ${ }^{\mathrm{TM}}$, Mallinckrodt Medical Ltd., Athlone, Ireland) that was lubricated with $2 \%$ lidocaine.

After insertion of a thoracic epidural catheter, anesthesia was induced with fentanyl $(0.1 \mathrm{mg})$ and propofol $(1.5 \mathrm{mg} / \mathrm{kg})$ or sevoflurane $(1-3 \%)$, followed by vecuronium $(0.1 \mathrm{mg} / \mathrm{kg})$. The DLT was inserted by a skilled anesthesiologist. The size of the leftsided DLT was selected based on the different factors for each patient : height, weight, sex, and measurement of the left bronchial diameter on chest radiograph or computer tomographic $\operatorname{scan}^{7}$. Nitrous oxide was avoided, in order to minimize changes in cuff volume due to gas diffusion. After auscultation of both sides of the chest, proper positioning of the DLT was confirmed by fiberoptic bronchoscopy. We determined the correct position of the DLT by two methods. First, the left second carina was observed clearly using fiberoptic bronchoscopy via the bronchial lumen of the DLT. Secondly, the edge of the bronchial cuff was able to be seen slightly via the tracheal lumen of the DLT. In order to measure the cuff pressures, the pilot balloon was connected to two control inflators (VBM CE0047, VBM Medizintechnik, Sulz, Germany) via the three-way stopcocks. While confirming the respiratory sounds in both upper lung fields, we inflated both cuffs with the minimum volume of air necessary to enable isolated lung ventilation in both lungs by alternately clamping each part of the two proximal tube lumens. The minimum inflation volume to avoid gas leakage was confirmed at an intra-airway pressure of $18 \mathrm{cmH}_{2} \mathrm{O}$.

Following measurement in the supine position, the patient was put into the lateral position. Both tracheal $(\mathrm{Pt})$ and bronchial cuff pressures $(\mathrm{Pb})$ were continuously monitored while the position was changed. After the position was changed, we confirmed again the bronchial tube placement and its cuff using a fiberoptic bronchoscope.

\section{Statistical analysis}

Analysis was performed using a statistical software package (SPSS 10.0 for Windows, SPSS Inc., Chicago, Illinois, USA). Comparison between different position points was made by paired-sample $t$ test. Statistical significance was defined as $P<0.05$.

\section{Result}

Demographic data and the site of lateral positions are shown in Table 1. The minimum inflation volumes in the supine position were $4.8 \pm 1.7$ and $1.5 \pm 0.7 \mathrm{~mL}$ in the tracheal and bronchial cuffs, respectively. 
Table 1 Demographic data of patients and site of lateral positions

\begin{tabular}{lc}
\hline Age $(\mathrm{yrs})$ & $57 \pm 12$ \\
Weight $(\mathrm{kg})$ & $52 \pm 9$ \\
Height $(\mathrm{cm})$ & $160 \pm 10$ \\
Male/Female & $9 / 9$ \\
Lateral position (right/left) & $6 / 12$ \\
\hline
\end{tabular}

Values are mean $\pm \mathrm{SD}$ or number.

Table 2 Changes of each cuff pressure in the different position

\begin{tabular}{lcc}
\hline & Tracheal cuff & Bronchial cuff \\
\hline Supine $\left(\mathrm{cmH}_{2} \mathrm{O}\right)$ & $21.7 \pm 2.4$ & $21.2 \pm 2.4$ \\
Lateral $\left(\mathrm{cmH}_{2} \mathrm{O}\right)$ & $20.0 \pm 5.8$ & $15.2 \pm 7.8^{*}$ \\
Pressure $\left(\mathrm{cmH}_{2} \mathrm{O}\right)$ & $-1.7 \pm 5.5$ & $-5.8 \pm 7.2$ \\
\hline
\end{tabular}

Values are mean \pm SD.

${ }^{*} \mathrm{p}<0.05$ versus bronchial cuff pressure in the supine position.

When patients were put into the lateral position, a significant decrease in the $\mathrm{Pb}$ was observed $(P=0.003$, Table 2$)$. The decreases in cuff pressure were $-1.7 \pm 5.5$ and $-5.8 \pm 7.2 \mathrm{cmH}_{2} \mathrm{O}$ for the $\mathrm{Pt}$ and $\mathrm{Pb}$, respectively. Although some cases exhibited increases in both the $\mathrm{Pt}$ and $\mathrm{Pb}, \mathrm{Pb}$ pressure decreased in most cases following the change in position. Thirteen cases exhibited a decrease in the $\mathrm{Pb}$ in the lateral position. In six of them (33.3\%), the $\mathrm{Pb}$ decreased quickly by more than $10 \mathrm{cmH}_{2} \mathrm{O}$ after shifting to the lateral position(Fig.1). In each of these cases, the bronchial cuff's had partly slipped out of position. However, in seven cases in which the change in $\mathrm{Pb}$ was less than $10 \mathrm{cmH}_{2} \mathrm{O}$, we confirmed that the bronchial cuffs were in the same place as when in the supine position (Table 3).

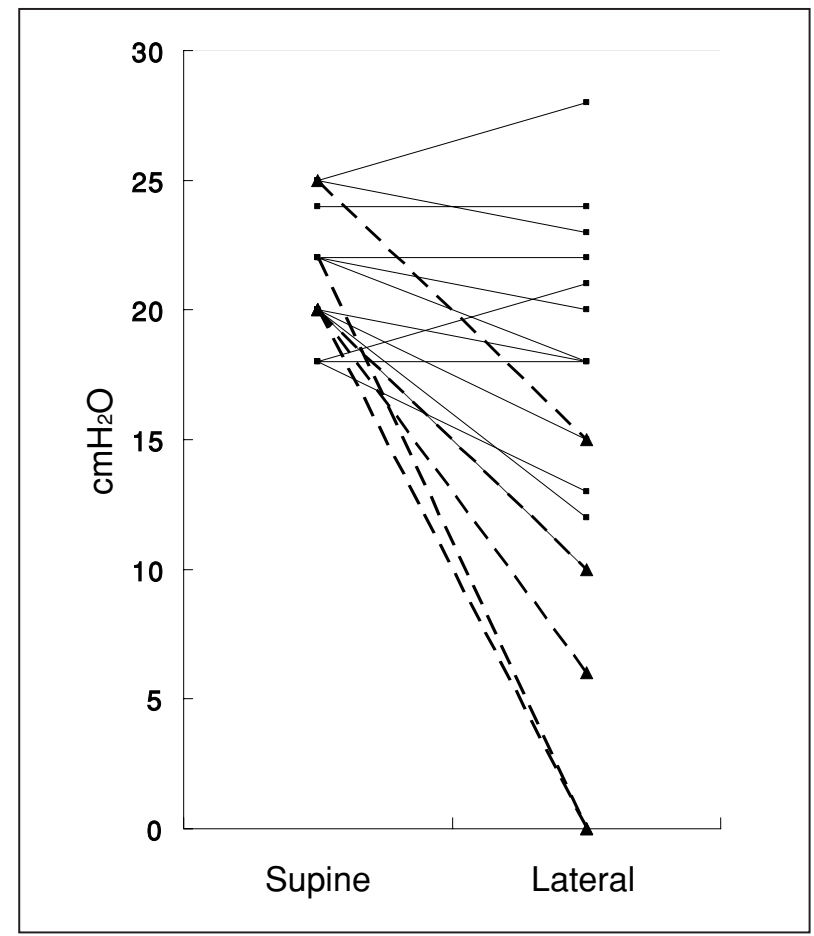

Fig.1 Changes of bronchial cuff pressure $(\mathrm{Pb})$ from the supine to the lateral position

The dotted lines are cases that showed a rapid decrease by more than $10 \mathrm{cmH}_{2} \mathrm{O}$ and their bronchial cuffs were confirmed to be slipped out from the main bronchus.

\section{Discussion}

DLT has been introduced to achieve isolation of the lungs during thoracic surgery ${ }^{1,2), 8}$. Therefore, maintenance of an appropriate cuff pressure and proper positioning of the bronchial cuff are required to avoid the risk of gas leakage (failure of isolation) and aspiration. It is recommended that cuff pressure be monitored carefully to avoid under - and over-inflation of DLT cuffs ${ }^{6)}$. However, Stewart et al.9) demonstrated that less than onethird of anesthesia providers inflated the cuff within an optimal range. They concluded that the techniques for estimation of cuff inflation are inadequate and suggested that direct measurement 
Table 3 Change in bronchial cuff pressure due to different positions and cuff status

\begin{tabular}{lcc}
\hline & $\ln (\mathrm{n}=12)$ & Slipped out $(\mathrm{n}=6)$ \\
\hline Supine $\left(\mathrm{cmH}_{2} \mathrm{O}\right)$ & $21.2 \pm 2.6$ & $21.2 \pm 2.0$ \\
Lateral $\left(\mathrm{cmH}_{2} \mathrm{O}\right)$ & $19.3 \pm 4.7$ & $6.8 \pm 6.0^{*}$ \\
$\Delta$ Pressure $\left(\mathrm{cmH}_{2} \mathrm{O}\right)$ & $-2.1 \pm 3.0$ & $-14.0 \pm 5.5$ \\
(Range) & $(+3--8)$ & $(-10--22)$ \\
\hline
\end{tabular}

Values are mean \pm SD.

${ }^{*} \mathrm{p}<0.05$ versus bronchial cuff pressure in the supine position.

should be utilized.

Newer ultra-thin polyurethane cuff membranes have been utilized to prevent liquid flow around cuffs inflated to only $15 \mathrm{cmH}_{2} \mathrm{O}^{10)}$. However, the DLT bronchial cuff is of a different shape and material compared with ordinary tubes. In the present study, we inflated the cuffs to avoid leakage when the intra-airway pressure was $18 \mathrm{cmH}_{2} \mathrm{O}$ according to the report of Brodsky et $\mathrm{al}^{8}{ }^{8}$. The present inflation volumes of $4.8 \mathrm{~mL}$ in the tracheal cuff and $1.5 \mathrm{~mL}$ in the bronchial cuff were similar to the results of Karasawa et al. ${ }^{6}$. They reported that the minimum air volumes that would not allow leakage when the intra-airway pressure reached 18 $\mathrm{cmH}_{2} \mathrm{O}$ were $5.8 \pm 1.6 \mathrm{~mL}($ mean $\pm \mathrm{SD}$ ) and $1.5 \pm 0.5$ $\mathrm{mL}$ in the tracheal and bronchial cuffs, respectively. Therefore, we consider that the methods utilized in the present investigation were appropriate.

In the present study, we found that both $\mathrm{Pt}$ and $\mathrm{Pb}$ changed with the position of the patient. Though the $\mathrm{Pb}$ decreased in the lateral position significantly, the Pt change was not significant in the lateral position. Similar results have also been reported $^{4,10), 11)}$ and have been well-established among anesthesiologists. Desiderio et al. ${ }^{11)}$ reported that inflating the bronchial cuff did not stabilize the position of the DLT when the patient was turned to the lateral position, since there was significant tracheal movement in 40 out of 50 patients with a mean of $0.9 \pm 1.0 \mathrm{~cm}$. Some physicians have recommended that both cuffs should be deflated during the change in the patient's position. However, in the present study the cuff was kept inflated to determine the degree of decrease before and after the change in position.

Six cases $(33.3 \%)$ exhibited a rapid decrease in cuff pressure of more than $10 \mathrm{cmH}_{2} \mathrm{O}$, and the bronchial cuffs were partially slipped out of position in each of these cases. Although there have been several investigations suggesting that the decrease of $\mathrm{Pb}$ might be indicative of slippage of the bronchial tube ${ }^{5,6)}$, we were not able to find any reports of concrete data to support that a "decrease in the $\mathrm{Pb}$ of more than $10 \mathrm{cmH}_{2} \mathrm{O}$ indicates slippage of the bronchial tube". If the bronchial tube partly slips out from the main bronchus, either during the positional change before surgery or during surgery, surgical manipulation must be terminated due to the risk of ventilation failure of the independent lung and potential aspiration into the dependent lung. It is usually not possible to continuously observe the cuff location using fiberoptic bronchoscope during surgery. Therefore, in most cases ; the anesthesiologist con- 
firms the position of the cuff visually with suggestions from the surgeons or due to signs of inadequate ventilation. Slippage of the bronchial cuff might be caused by surgical manipulation, and on occasion, the surgeon might rupture the cuff. Therefore, the $\mathrm{Pb}$ should be carefully monitored from the start of anesthesia through the end of surgery.

In seven cases in which cuff pressure change was less than $10 \mathrm{cmH}_{2} \mathrm{O}$, we confirmed the bronchial cuffs were in the same place as when in the supine position. We investigate the movement of mediastinum from the supine to the lateral positions might have affected the cuff pressure. Especially because of the effect of the heart, the left lateral position might have decreased the $\mathrm{Pb}$.

We observed a few cases that exhibited an increase of $\mathrm{Pt}$ and $\mathrm{Pb}$ when the position of the patient was changed. Brimacombe et al. ${ }^{12)}$ demonstrated that, compared with the neutral position, cuff pressures increased in the rotated, extended and flexed positions. In the present study, we speculate that the rotation or flexion of the tube elicited the increase in cuff pressures when the position of the patient was changed. However, since we did not observe any rotation or flexion of the bronchial cuff in the present study, it will be necessary to confirm such changes in future investigations. We consider that fiberoptic bronchoscope should be used properly to determine sliding, rotation, or flexion of the bronchial cuff. For this purpose, continuous monitoring of $\mathrm{Pb}$ pressure may also might be useful.

In conclusion, although the bronchial cuff pressure decreased by changing from the supine to the lateral positions, as reported previously, a rapid decrease in bronchial cuff pressure of more than 10
$\mathrm{cmH}_{2} \mathrm{O}$ might strongly suggest slippage of the bronchial tube. Continuous monitoring of bronchial cuff pressure is useful to detect slippage of the bronchial cuff.

This study was performed by Dr Yihong Jiang, at Hamamatsu University School of Medicine, from September 2005 to March 2006.

\section{References}

1) Lewis JW Jr, Serwin JP, Gabriel FS, et al. : The utility of a double-lumen tube for one-lung ventilation in a variety of noncardiac thoracic surgical procedures. J Cardiothorac Vasc Anesth $6: 705^{-710,} 1992$

2) Kelley JG, Gaba DM, Brodsky JB : Bronchial cuff pressures of two tubes used in thoracic surgery. J Cardiothorac Vasc Anesth 6 : 190-192, 1992

3) Bahk JH, Lim YJ, Kim CS : Positioning of a doublelumen endobronchial tube without the aid of any instruments : an implication for emergency management. J Trauma $49:$ 899-902, 2000

4) Yoon TG, Chang HW, Ryu HG, et al. : Use of a neck brace minimizes double-lumen tube displacement during patient positioning. Can J Anaesth 52 : 413-417, 2005

5) Araki K, Nomura R, Urushibara R, et al. : Bronchial cuff pressure change caused by left-sided doublelumen endobronchial tube displacement. Can J Anaesth 47 : 775-779, 2000

6) Karasawa F, Takita A, Takamatsu I, et al. : Rapid deflation of the bronchial cuff of the double-lumen tube after decreasing the concentration of inspired nitrous oxide. Anesth Analg 95 : 238-242, 2002

7) Araki K, Nomura R, Urushibara R, et al. : Displacement of the double-lumen endobronchial tube can be detected by bronchial cuff pressure change. Anesth Analg 84 : 1349-1353, 1997

8) Brodsky JB, Macario A, Mark JB : Tracheal diameter predicts double-lumen tube size : a method for selecting left double-lumen tubes. Anesth Analg 82 : 861864, 1996

9) Stewart SL, Secrest JA, Norwood BR, et al. : A comparison of endotracheal tube cuff pressures using estimation techniques and direct intracuff measurement. AANA J $71: 443-447,2003$ 
10) Dullenkopf A, Gerber A, Weiss M : Fluid leakage past tracheal tube cuffs : evaluation of the new Microcuff endotracheal tube. Intensive Care Med 29 : 1849-1853, 2003

11) Desiderio DP, Burt M, Kolker AC, et al. : The effects of endobronchial cuff inflation on double-lumen endobronchial tube movement after lateral decubitus posi- tioning. J Cardiothorac Vasc Anesth 11 : 595-598, 1997

12) Brimacombe J, Keller C, Giampalmo M, et al. : Direct measurement of mucosal pressures exerted by cuff and non-cuff portions of tracheal tubes with different cuff volumes and head and neck positions. Br J Anaesth $82: 708-711,1999$

\title{
急速な気管支カフ圧の減少は気管支カフの逸脱を示唆する
}

\author{
蒋 奕江*1,3 白石義人*2 青木善孝*3 佐藤重仁*3 \\ ${ }^{* 1}$ 桂林医科大学麻酔科学講座 (中国) \\ *2浜松医科大学附属病院手術部 \\ $* 3$ 浜松医科大学麻酔 $\cdot$ 蘇生学, 集中治療講座
}

[目的］この研究の目的は, 仰臥位から側臥位に体位変換することにより気管支腔から気管支カフの逸 脱を示唆する，気管支カフ圧の減少值を調べることにある.

[方法］全身麻酔導入後，二腔気管チューブ $(\mathrm{DLT})$ で気管抻管した $(\mathrm{n}=18)$ ．DLTの位置を気管支ファ イバースコープで確認した後, 気管, 気管支両方のカフが漏れのないよう最少量の空気を注入した。両 側のカフ圧変化は仰臥位から側臥位に体位変換後に記録した．気管支カフの位置を気管支ファイバース コープで確認し, カフの逸脱の程度とカフ圧の変化の関係について調べた.

[結果］気管カフ圧は仰臥位で $21.2 \pm 2.4 \mathrm{cmH}_{2} \mathrm{O}$ から側臥位で $15.2 \pm 7.8 \mathrm{cmH}_{2} \mathrm{O}$ (平均 $\pm \mathrm{SD}, P=0.003$ ) に減少した. 6 症例では急速に $10 \mathrm{cmH}_{2} \mathrm{O}$ 以上のカフ圧減少を認め, 6 症例すべてで気管支腔から気管支 カフが逸脱しているのを認めた.

[結論］二腔気管チューブ(DLT)の気管支カフ圧は仰臥位から側臥位の体位変換で減少した。気管支カ フ圧の急速な減少 $\left(10 \mathrm{cmH}_{2} \mathrm{O}\right.$ 以上) は気管支腔からの気管支カフの逸脱によるものであった．気管支カ

フ圧の持続的なモニタリングは気管支カフの逸脱を検知するのに有用である.

Key Words : 気管支カフ圧, 二腔気管チューブ, 気管支カフ逸脱 